\title{
CRITICAL SUCCESS FACTORS OF ERP/CRM IMPLEMENTATION IN SMES IN POLAND: PILOT STUDY
}

\author{
Małgorzata CIECIORA ${ }^{1 *}$, Wiktor BOŁKUNOW ${ }^{2}$, Piotr PIETRZAK $^{3}$, Piotr GAGO ${ }^{4}$, \\ Małgorzata RZEŹNIK-KNOTEK ${ }^{5}$ \\ ${ }^{1}$ Polish-Japanese Academy of Information Technology, Faculty of Information Management, Warsaw; \\ Malgorzata.Cieciora@pja.edu.pl, ORCID: 0000-0002-4161-4653 \\ ${ }^{2}$ Collegium of Management and Finance, Warsaw School of Economics, Warsaw; wbolk@sgh.waw.pl, \\ ORCID: 0000-0002-1480-1031 \\ ${ }^{3}$ Management Institute, Warsaw University of Life Sciences, Warsaw; piotr_pietrzak1@sggw.pl, \\ ORCID: 0000-0002-1319-4815 \\ ${ }^{4}$ Faculty of Information Technology, Polish-Japanese Academy of Information Technology, Warsaw; \\ pgago@pja.edu.pl, ORCID: 0000-0001-7288-4210 \\ ${ }^{5}$ Faculty of Information Management, Polish-Japanese Academy of Information Technology, Warsaw; \\ Malgorzata.Rzeznik@pja.edu.pl, ORCID: 0000-0001-7912-3406 \\ *Correspondence author
}

Purpose: The purpose of this study was to define Critical Success Factors (CSFs) of implementation of CRM (Customer Relationship Management) and ERP (Enterprise Resource Planning) systems in small and medium-sized enterprises (SMEs) in Poland.

Design/methodology/approach: Data was obtained from 83 respondents with work experience in SMEs in Poland that had undergone the implementation of an ERP/CRM system or the systems vendors. It was collected in the form of Google Form surveys and was analysed with the use of Spearman's rank order correlation.

Findings: The key CSFs comprise a thorough pre-implementation analysis and ensure sufficient financial resources for the implementation. Good communication between the ICT (Information and Communication Technologies) vendor and the SME's employees, skills and experience of the vendor, as well as thorough preparation and familiarisation with the contract before implementation by both parties are also relevant.

Research limitations/implications: The study limitations include a lack of research on a larger sample. Further work should cover the main barriers and threats connected with the implementation of ICT in SMEs in Poland and the ways of overcoming them.

Practical implications: The findings can help SMEs' decision-makers to prioritise the factors they have to take into account during planning an ICT implementation.

Originality/value: This paper has highlighted the relevance of key CSFs in ICT implementation. The findings substantially add to the growing literature on digitalisation of SMEs.

Keywords: Critical Success Factors, CRM, ERP, SMEs, Poland.

Category of the paper: Research paper. 


\section{Introduction}

In the times of dynamically developing ICT (Communication Technologies), one of the contemporary pillars of economic growth (Máté et al., 2020), enterprises all around the world are increasingly deciding to acquire, implement and use IT systems supporting the functioning of organisations, such as ERP (Enterprise Resource Planning) or CRM (Customer Relationship Management). Well-selected and properly-used systems can significantly increase the efficiency of a company's operations by enabling them to quickly collect, organise and analyse various data or to improve the flow of information within a company and with external stakeholders. The enterprise resource management process can be supported by ERP systems (Nagy et al., 2018, Dudziak et al., 2017; Wyskwarski, 2017; Grochowski, 2016). Their goal is the fullest possible integration of all levels of management, all supply processes, production and other activities of a company (Cieśla et al., 2018; Wolniak, 2005, 2017; Wolniak and Habek, 2014). The measurable benefits of using ERP systems include, for example, optimisation of costs and inventory, accounting for the efficiency of company resources and shortening the lead time. Thanks to CRM systems, one can, among other things, make multidimensional customer segmentation and automate marketing and sales. In practice, a majority of big companies (employing over 250 employees) use such systems; the situation is not as bright when it comes to enterprises from the SME sector. They, in general, have a much lower Digital Intensity Index, an indicator used by Eurostat to measure the digital maturity of companies whose components include the use of CRM and ERP software. According to Statistics Poland, in 2017 in Poland, as many as $40.2 \%$ of big companies and as few as $11.7 \%$ of SMEs had high or very high digital intensity (GUS, 2017, p. 113). It is worth mentioning that SMEs do not tend to employ specialists with digital competencies, such people are employees of less than $7 \%$ of small and $29 \%$ of medium-sized companies, as compared to $73.5 \%$ of big companies in Poland (PARP, 2018, p. 64). As a rule, SMEs have more limited resources - financial, human or knowledge - than corporations. Therefore, they have limited resources for budgeting IT projects (Rostek et al., 2012). One could formulate an assumption, though, that a well-functioning IT system would significantly simplify the work of SMEs and, in a way, make up for the lack of various resources they have to constantly struggle with. A thoroughly prepared and properly executed implementation of an IT system can thus be considered as a financially rewarding investment. It should be stressed here that SMEs play an important role in the economic development of Poland (Kokot-Stępień, 2017; Zastempowski and Glabiszewski, 2017; Grzeszczak, 2018). According to PARP (Polish Agency for Enterprise Development), companies operating in Poland generated nearly three quarters $(74.0 \%)$ of Polish GDP in 2015, and the largest contribution to enterprises' GDP was made by SMEs, which accounted for almost half (49.9\%) of the GDP. They also create a majority of workplaces 
- in 2016, nearly 6.7 million people, i.e. $68.7 \%$ of all employees in the enterprise sector in Poland were employed by SMEs (PARP, 2018, pp. 17, 21). Therefore, issues regarding the success factors of the implementation of systems such as ERP and CRM in companies from the SME sector should be considered an important research question. It should be stressed here that there are also other ICT systems that support decision-making systems or process management in companies; the selection of the two systems for the present study was based primarily on the fact that they were chosen as the key indicators tracking digitisation processes of EU28 enterprises in the aforementioned Digital Intensity Index (DII) used by Eurostat (Eurostat, 2018).

\section{Methods}

In order to investigate the research question, the study was organised according to the steps presented in Figure 1.

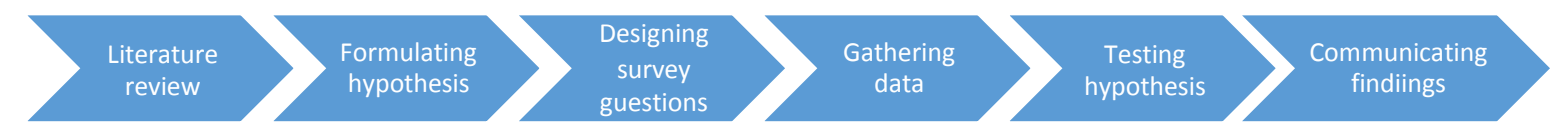

Figure 1. Research framework.

The aim of this study was to define the main Critical Success Factors (CSFs) of the implementation of ERP and CRM systems in SMEs in Poland. One hypothesis was made based on a literature review and the objectives of the study:

H1: 1. The main CFSs of the implementation of ERP/CRM systems in SMEs in Poland are: a thorough pre-implementation analysis and ensuring a sufficient amount of financial resources for the implementation.

First, a brief literature review of the CSFs of the implementation of ERP/CRM systems in SMEs is presented. Next, the results of 83 surveys conducted with ICT specialists with experience in implementation of ERP/CRM systems in Poland and workers of SMEs in which ERP/CRM systems were implemented are presented and discussed. Finally, the conclusions and a summary are presented. 


\section{Results}

\subsection{Literature Review}

\subsubsection{Critical Success Factors (CSFs) of ICT Adoption in SMEs - International Studies}

In literature on the subject, one can find many studies on the factors that can impact the adoption of ICT, such as ERP or CRM, in SMEs. These factors are often referred to as critical success factors (CSFs) (Rockart, 1979; Somers and Nelson, 2001; Esteves-Sousa and PastorCollado, 2000; Ahmad and Cuenca, 2013, Doom et al., 2010; Sun et al., 2005). The Critical Success Factors were defined by Rockart (1979) as “... the limited number of areas in which results, if they are satisfactory, will ensure successful competitive performance for the organisation. They are the few key areas where things must go right for the business to flourish. If results in these areas are not adequate, the organisation's efforts for the period will be less than desired". According to a literature review conducted by Ahmad and Cuenca (2013), the most often highlighted CSFs include management support, interdepartmental communication, business process re-engineering, project team skills, interdepartmental cooperation, project management, evaluation progress and clear goals and objectives. They were also classified in three categories: organisational CSFs (organisational and cultural factors, e.g. formalised project plan or interdepartmental communication), operational CSFs (operational and technical factors, e.g. adequate resources or software configuration) and neutral CSFs (those factors which could not be clearly defined as belonging to one of the previously mentioned groups, e.g. interdepartmental cooperation or software customisation). Ahmad and Cuenca (2013) put the CSFs into scrutiny and found out that organisational factors play a more critical role than operational factors. They also proposed grouping the most significant CSFs into three different interaction categories: basic (which impact other CSFs, but others do not significantly impact them), critical (which are impacted by the basic factors and also have a notable impact from others) and dependent (which are highly impacted by other CSFs). Basic CSFs are: project team skills, experienced project manager, resources and data analysis; they are associated with the initial stage of the project and the willingness to implement the system. Critical CSFs are related to the implementation process of the system within the organisation and include: cultural change, use of consultants and management support. Finally, dependent CSFs, connected with the process of tuning the system to make it as beneficial as possible, include: cooperation, evaluation progress and communication.

Another division and nomenclature of factors that can influence adoption of ICT systems in SMEs were proposed by Alshawi, Missi and Irani (2011). After conducting a literature review, they categorised the following groups of potential influencers in CRM adoptions in SMEs: organisational factors, technical factors and data quality factors. Organisational factors relate directly or indirectly to the structural, operational, human and managerial aspects of the SME. Technical factors relate to the soft and hard aspects of the ICT/CRM technology being 
adopted. Data quality factors relate directly to the concept of data quality and how it is being conducted in the context of CRM adoption. The authors of the study conducted empirical multicase study in the UK and identified the following factors as the most influential during the adoption of CRM: (a) organisational: Benefits; Staff ICT skills; Managerial ICT skills; Organisation size; Support; Funding; Strategy; Business objectives; Customer response/ attitude; Government; Competitive pressure; Suppliers; (b) technical: ICT infrastructure; Purchase, Implementation and integration cost; System evaluation and selection criteria; Complexity; Integration; Vendor after sale support; Software selection criteria; (c) data quality factors: Evaluation of the Data Quality Tools and Processes; Evaluation of the quality of customer data; Customer data infrastructure; Customer data sources classification.

Another comprehensive literature review on ERP systems in SMEs was conducted by Haddara and Zach (2011). As far as studies on the implementation phase are concerned, they identified papers devoted to previously mentioned CSFs, SME characteristics, impact of consultants and risk management. There is mixed evidence concerning the role of external consultants - on the one hand, "experienced consultants can play an important role in correcting their clients' 'unrealistic expectations'" (Adam and O'Doherty, 2000); on the other hand, though, the implementation of an SME specific ERP system might not need external consultancy, which would significantly lower the cost of the project (Koh et al., 2009).

\subsubsection{Implementation of ERP/CRM Systems in SMEs in Poland}

As far as studies on implementation of ERP/CRM systems in SMEs in Poland are concerned, the research is quite limited. A brief literature review on the implementing and functioning of CRM systems in SMEs was presented by Kmieciak (2010). One of the main findings, important from the point of view of SMEs' decision-makers, was that the usefulness of a CRM is related to the profile of the company. Companies providing maintenance and insurance services, tourist offices or real estate agencies which have to rely to a large extent on accurate and fast information, effective marketing, direct and timely delivery of tasks are more likely to benefit from the functions that a CRM offers than local retailers. Before implementing a CRM system in a small or medium enterprise, one should, first of all, analyse whether it will be useful for the company.

Finally, it should also be mentioned in the context of studies on CRM/ERP adoption in SMEs in Poland that research has been conducted on the ICT maturity of SMEs in Poland in general (Śledziewska et al., 2015). Some of its findings may be useful for the analysis of CSFs of implementation of IT systems. It should be noted, above all, that SMEs in Poland seem to have relatively low digital competences, both in terms of organisations as whole units and in terms of their individual employees. The main reasons include seeing no need to use new technology, the conservative mindset of Polish companies, the difficulties in recruiting good employees and a lack of marketing maturity. As the companies do not see the potential of new technologies and see no need in implementing ICT innovations, they do not require a high level 
of digital competences from their employees, and they neither want to pay for them nor invest in them. Polish SMEs expect just basic IT competences (computer skills, using the MS Office suite) and, rarely, other skills related to using new technologies, such as a sophisticated search for information. They also have little knowledge about using cloud computing and are afraid of trying such solutions. In general, average Polish entrepreneurs mainly use conservative strategies.

\subsection{Results of Surveys on CSFs of ERP/CRM Implementation in SMEs Conducted Among ICT Specialists and Workers of SMEs in Poland}

\subsubsection{Description of Surveys}

Surveys regarding CSFs for CRM/ERP implementation in SMEs in Poland were carried out from 7 December to 23 December 2019 via an online Google Form. The surveys were designed by the authors of the study on the basis of a literature review and the objectives of the study. The selection of the sample was purposeful. The respondents were (in total 83): (1) ICT specialists with experience of implementing ERP/CRM systems in SMEs in Poland or (2) workers of SMEs with experience of implementing ERP/CRM systems in SMEs in Poland. They were graduates and students of the Warsaw School of Economics, Polish-Japanese Academy of Information Technology in Warsaw, Poland, and members of a closed Facebook group created by systems developers "SysOps/DevOps Polska". The respondents were asked to evaluate the significance of 9 CSFs for CRM/ERP implementation in SMEs in Poland using a 5-point Likert scale. The criteria were ordered according to the total share of "important" and "very important" responses in the respondents' assessment (Tables 1, 2, 3).

\subsubsection{Results of Surveys}

Respondents were divided according to: gender, level of education, position/role during the implementation of the ERP/CRM system, years of experience in the implementation/use of ERP/CRM systems. Males were dominant in the study group (75.9\%). People with higher education constituted nearly half of the respondents. Most respondents $-50.0 \%-$ were employees of companies in which an ERP/CRM system was implemented. Technical employees of external companies implementing the system constituted $33.8 \%$ of the research sample. Respondents who were the owners/decision-makers of SMEs in which the system was implemented amounted to $6.3 \%$, while the owners/decision-makers of external companies responsible for implementation of the system constituted $3.8 \%$ of the sample. The remaining part of the respondents occupied different positions or had a different role during the implementation of the systems. Among them were: programmers, testers, system auditors. More than half of the respondents $(57.3 \%)$ were people with 1 to 5 years of experience. $11.0 \%$ of those surveyed had more than 5 years of experience. The SME sector companies in which the respondents were employed were related to education, telecommunications, FMCG, pharmacy and energy. The answers received show that the factors that are crucial for the 
successful implementation of CRM/ERP systems in the SME sector are: a thorough analysis of the company's needs (a total of $91.2 \%$ of respondents indicated that this factor is "very important" or "important"), having sufficient financial resources (89.9\%) and good communication between the implementation service provider and SME employees $(88.7 \%)$. By contrast, the least important are: the employment of external consultants for the pre-implementation analysis of the company's needs (a total of $38.0 \%$ of respondents indicated that this is a factor "completely unimportant" or "not important") and the reorganisation of SMEs, including work organisation and incentive system to the conditions after the implementation of the new IT system (17.6\%) (Table 1).

Table 1.

Importance of CSFs of implementation of CRM/ERP systems in Polish SMEs according to all respondents' opinions [\%]

\begin{tabular}{|c|c|c|c|c|c|c|}
\hline \multirow[b]{2}{*}{ Rank } & \multirow[b]{2}{*}{ CSF } & \multicolumn{5}{|c|}{ Importance of CSF } \\
\hline & & $\begin{array}{c}\text { Very } \\
\text { important }\end{array}$ & Important & $\begin{array}{l}\text { Difficult } \\
\text { to say }\end{array}$ & $\begin{array}{c}\text { Not } \\
\text { important }\end{array}$ & $\begin{array}{c}\text { Completely } \\
\text { unimportant }\end{array}$ \\
\hline 1. & $\begin{array}{l}\text { Thorough pre- } \\
\text { implementation analysis of } \\
\text { the company's needs }\end{array}$ & 55.8 & 35.4 & 2.5 & 3.8 & 2.5 \\
\hline 2. & $\begin{array}{l}\text { Having sufficient financial } \\
\text { resources }\end{array}$ & 35.4 & 54.5 & 7.6 & 0.0 & 2.5 \\
\hline 3. & $\begin{array}{l}\text { Good communication } \\
\text { between the implementation } \\
\text { service provider and the } \\
\text { SME's employees }\end{array}$ & 54.5 & 34.2 & 6.3 & 2.5 & 2.5 \\
\hline 4. & $\begin{array}{l}\text { Thorough preparation and } \\
\text { familiarisation with the } \\
\text { contract before } \\
\text { implementation by both } \\
\text { companies (the } \\
\text { implementation service } \\
\text { provider and the SME) }\end{array}$ & 29.1 & 57.0 & 8.9 & 1.2 & 3.8 \\
\hline 5. & $\begin{array}{l}\text { Skills and experience of the } \\
\text { implementation service } \\
\text { provider }\end{array}$ & 30.4 & 53.2 & 6.3 & 7.6 & 2.5 \\
\hline 6. & $\begin{array}{l}\text { Preparation of the SME's } \\
\text { employees to implement and } \\
\text { use the system before starting } \\
\text { the implementation }\end{array}$ & 36.7 & 40.5 & 10.1 & 8.9 & 3.8 \\
\hline 7. & $\begin{array}{l}\text { Support of the SME's } \\
\text { managers }\end{array}$ & 31.6 & 40.5 & 16.5 & 7.6 & 3.8 \\
\hline 8. & $\begin{array}{l}\text { Reorganisation of the SME, } \\
\text { including work organisation } \\
\text { and incentive system to the } \\
\text { conditions after the } \\
\text { implementation of the new } \\
\text { IT system }\end{array}$ & 20.3 & 38.0 & 24.1 & 12.6 & 5.0 \\
\hline 9. & $\begin{array}{l}\text { Employment of external } \\
\text { consultants for pre- } \\
\text { implementation analysis of } \\
\text { the company's needs }\end{array}$ & 5.0 & 26.6 & 30.4 & 26.6 & 11.4 \\
\hline
\end{tabular}

Source: own study. 
The next step of the analysis was to check if there are differences in the perception of the success factors between respondents occupying different positions and performing different functions during the implementation of ERP/CRM systems. Therefore, the research sample was divided into two groups: (1) people employed in the companies responsible for system implementation (decision-makers/owners and technical employees) and (2) people employed in SMEs in which the systems were implemented (decision-makers/owners and technical employees). Respondents who indicated the answer "other" in the section concerning "employment" were excluded from this analysis.

For both groups of respondents, the most important factor for the successful implementation of CRM/ERP in the SME sector was a thorough pre-implementation analysis of the company's needs (Tables 2 and 3). A total of $96.7 \%$ of respondents in group 1 and $87.5 \%$ in group 2 indicated that this is a "very important" and "important" factor. It is worth emphasising that in group 1, this CSF shared the highest position, ex aequo, with "having sufficient financial resources", and in group 2, with "good communication with an external company". It is worth noting that the importance of other criteria varied in the two groups. For example, the next important factor in group 1 was thorough preparation and familiarisation with the contract before implementation by the client and the vendor, while group 2 valued higher skills and experience of the vendor and having sufficient financial resources (Tables 2 and 3 ).

It is worth noting that in the opinion of both groups of respondents, the least important factors were: the employment of external consultants to analyse the pre-implementation needs of the company (which, as the only criterion analysed, earned even less "very important" and "important" answers than "not important" and "completely unimportant") and the reorganisation of SMEs, including work organisation and incentive system to the conditions after the implementation of the new IT system.

Table 2.

Importance of CSFs of implementation of CRM/ERP systems in Polish SMEs according to the opinions of employees of external companies responsible for the implementation of systems [\%]

\begin{tabular}{|c|c|c|c|c|c|c|}
\hline \multirow[b]{2}{*}{ Rank } & \multirow[b]{2}{*}{ CSF } & \multicolumn{5}{|c|}{ Importance of CSF } \\
\hline & & $\begin{array}{c}\text { Very } \\
\text { important }\end{array}$ & Important & $\begin{array}{c}\text { Difficult } \\
\text { to say }\end{array}$ & $\begin{array}{c}\text { Not } \\
\text { important }\end{array}$ & $\begin{array}{c}\text { Completely } \\
\text { unimportant }\end{array}$ \\
\hline 1. & $\begin{array}{l}\text { Thorough pre-implementation } \\
\text { analysis of the company's } \\
\text { needs }\end{array}$ & 66.7 & 30.0 & 0.0 & 3.3 & 0.0 \\
\hline 1. & $\begin{array}{l}\text { Having sufficient financial } \\
\text { resources }\end{array}$ & 33.3 & 63.4 & 3.3 & 0.0 & 0.0 \\
\hline 3. & $\begin{array}{l}\text { Thorough preparation and } \\
\text { familiarisation with the } \\
\text { contract before } \\
\text { implementation by both } \\
\text { companies (the } \\
\text { implementation company and } \\
\text { the SME) }\end{array}$ & 30.0 & 63.4 & 3.3 & 0.0 & 3.3 \\
\hline
\end{tabular}


Cont. table 2.

\begin{tabular}{|c|c|c|c|c|c|c|}
\hline 4. & $\begin{array}{l}\text { Good communication between } \\
\text { the implementation service } \\
\text { provider and the SME's } \\
\text { employees }\end{array}$ & 63.4 & 26.6 & 10.0 & 0.0 & 0.0 \\
\hline 5. & $\begin{array}{l}\text { Skills and experience of the } \\
\text { implementation service provider }\end{array}$ & 33.3 & 50.0 & 6.7 & 10.0 & 0.0 \\
\hline 6. & $\begin{array}{l}\text { Preparation of the SME's } \\
\text { employees to implement and use } \\
\text { the system before starting the } \\
\text { implementation }\end{array}$ & 33.3 & 46.7 & 3.3 & 13.4 & 3.3 \\
\hline 7. & Support of the SME's managers & 36.7 & 36.7 & 20.0 & 3.3 & 3.3 \\
\hline 8. & $\begin{array}{l}\text { Reorganisation of the SME, } \\
\text { including work organisation and } \\
\text { incentive system to the } \\
\text { conditions after the } \\
\text { implementation of the new IT } \\
\text { system }\end{array}$ & 20.0 & 40.0 & 26.7 & 13.3 & 0.0 \\
\hline 9. & $\begin{array}{l}\text { Employment of external } \\
\text { consultants for pre- } \\
\text { implementation analysis of the } \\
\text { company's needs }\end{array}$ & 10.0 & 20.0 & 30.0 & 30.0 & 10.0 \\
\hline
\end{tabular}

Source: own study.

Table 3.

Importance of CSFs of implementation of CRM/ERP systems in Polish SMEs according to the opinions of employees of SMEs in which the systems were implemented [\%]

\begin{tabular}{|c|c|c|c|c|c|c|}
\hline \multirow[b]{2}{*}{ Rank } & \multirow[b]{2}{*}{ CSF } & \multicolumn{5}{|c|}{ Importance of CSF } \\
\hline & & $\begin{array}{c}\text { Very } \\
\text { important }\end{array}$ & Important & $\begin{array}{c}\text { Difficult } \\
\text { to say }\end{array}$ & $\begin{array}{c}\text { Not } \\
\text { important }\end{array}$ & $\begin{array}{c}\text { Completely } \\
\text { unimportant }\end{array}$ \\
\hline 1. & $\begin{array}{l}\text { Thorough pre- } \\
\text { implementation analysis of } \\
\text { the company's needs }\end{array}$ & 50.0 & 37.5 & 5.0 & 5.0 & 2.5 \\
\hline 1. & $\begin{array}{l}\text { Good communication } \\
\text { between the implementation } \\
\text { service provider and the } \\
\text { SME's employees }\end{array}$ & 50.0 & 37.5 & 5.0 & 5.0 & 2.5 \\
\hline 3. & $\begin{array}{l}\text { Having sufficient financial } \\
\text { resources }\end{array}$ & 32.5 & 52.5 & 12.5 & 0.0 & 2.5 \\
\hline 3. & $\begin{array}{l}\text { Skills and experience of the } \\
\text { implementation company }\end{array}$ & 27.5 & 57.5 & 7.5 & 5.0 & 2.5 \\
\hline 5. & $\begin{array}{l}\text { Thorough preparation and } \\
\text { familiarisation with the } \\
\text { contract before } \\
\text { implementation by both } \\
\text { companies (the } \\
\text { implementation service } \\
\text { provider and the SME) }\end{array}$ & 27.5 & 52.5 & 15.0 & 2.5 & 2.5 \\
\hline 6. & $\begin{array}{l}\text { Preparation of the SME's } \\
\text { employees to implement and } \\
\text { use the system before } \\
\text { starting the implementation }\end{array}$ & 37.5 & 37.5 & 15.0 & 7.5 & 2.5 \\
\hline 6. & $\begin{array}{l}\text { Support of the SME's } \\
\text { managers }\end{array}$ & 27.5 & 47.5 & 12.5 & 10.0 & 2.5 \\
\hline
\end{tabular}


Cont. table 3.

\begin{tabular}{|l|l|c|c|c|c|c|}
\hline 8. & $\begin{array}{l}\text { Reorganisation of the SME, } \\
\text { including work organisation } \\
\text { and incentive system to the } \\
\text { conditions after the } \\
\text { implementation of the new } \\
\text { IT system }\end{array}$ & 22.5 & 37.5 & 20.0 & 12.5 & 7.5 \\
\hline $9 . \quad \begin{array}{l}\text { Employment of external } \\
\text { consultants for pre- } \\
\text { implementation analysis of } \\
\text { the company's needs }\end{array}$ & 0.0 & 30.0 & 32.5 & 30.0 & 7.5 \\
\hline
\end{tabular}

Source: own study.

In the next step of the analysis, Spearman's rank correlation coefficient obtained for individual criteria in both groups was calculated. Ranks determined the position on which the criterion was found (in the study group) according to their importance. In the case of criteria that achieved an equal percentage of responses, the authors assigned them an arithmetic mean calculated from their subsequent numbers. Spearman's rank correlation coefficients had a positive direction and assumed a value of 0.89 . This means that there was a high correlation between the positions taken by individual success factors in both groups. In conclusion, there were no significant differences between the two groups of respondents in the perception of the importance of individual factors enabling success in the implementation of CRM/ERP in the SME sector.

\section{Discussion}

The literature review shows that CSFs of the implementation of CRM/ERP systems in SMEs include a wide array of factors, ranging from the attitude and analytical and strategic decision-making skills of SMEs owners, through the degree of the project team's ICT expertise and soft skills, ending with the quality of the CRM/ERP system, the SME's ICT infrastructure, as well as the cost of the purchase and implementation of the system. Prior research emphasised the role of such CSFs as management support, interdepartmental communication, business process re-engineering, project team skills, interdepartmental cooperation, project management, evaluation progress and clear goals and objectives. Some authors have also stressed the supremacy of organisational factors over operational or technical factors. The main conclusions that can be drawn from literature studies on the implementation of CRM/ERP systems in SMEs in Poland are that the factors which are of great importance also include the profile of the company, the (conservative) attitude of the company decision-makers to the use of modern technologies, such as ICT, as well as the digital competences of both the company as a whole and its individual workers. Last but not least, it should be noted that the role of the analysis of pre-implementation needs was also highlighted. 
These findings were at least partially supported by the results of surveys conducted among a sample of 83 practitioners with experience of CRM/ERP implementation in SMEs in Poland. The analysis of the survey answers showed that a majority of respondents, with either a "technical" background, i.e. workers or owners of the IT system vendor, or a "business" background, i.e. workers or owners of an SME that underwent implementation of such a system, agreed that the most important CSF in the implementation of CRM/ERP systems in Poland was a thorough pre-implementation analysis of the company's needs; having sufficient financial resources followed closely. Therefore, hypothesis 1, which assumed the high importance of these two CSFs, was verified positively. It is worth noting, however, that "business" respondents valued good communication with an external company slightly higher than financial backup. It should also be stressed that all the analysed CSFs, with the exception of "employment of external consultants for pre-implementation analysis of the company's needs", were regarded as relevant, which is in line with the findings of the literature review. The most intriguing result, though, to emerge from the data was the quite low rating of "reorganisation of the SME, including work organisation and incentive system to the conditions after the implementation of the new IT system", which may suggest that the strategic aspect of the implementation of an IT system has not been recognised yet.

\section{Summary}

The use of ICT solutions such as CRM and ERP systems can significantly influence the operational efficiency and, consequently, competitiveness and profitability of companies of all sizes. Nowadays, in modern, technology-driven market economies, it is literally becoming a must have even for the smallest companies, i.e. SMEs, due to the pressure of the competitive environment. Still, the decision to choose and implement such a system poses a challenge for decision-makers of SMEs, as it entails reengineering of the company and is costly in terms of money, time and energy. It also requires ICT expertise. For a majority of SMEs in Poland, which, especially in comparison to big companies, have a low digital intensity index, this is a luxury difficult to afford. One should bear in mind the fact that a poorly conducted implementation of a CRM/ERP system can deteriorate the overall situation of the company instead of improving it. Therefore, the aim of this study was to define the main Critical Success Factors of implementation of ERP and CRM systems in SMEs in Poland. One hypothesis was made in order to answer the research question. The analysis of surveys conducted among 83 practitioners with experience in implementing CRM/ERP systems in SMEs in Poland allowed for the positive verification of the hypothesis, which highlighted the importance of conducting a thorough pre-implementation analysis and collecting sufficient funds for the implementation. The research has also shown that, though the aforementioned factors are 
important, there are other, significant factors, such as good communication between the implementation company and the SME's employees, skills and experience of the implementation company or thorough preparation and familiarisation with the contract before implementation by both the ICT vendor and the SME. The only factor whose importance or even usefulness was questioned was resorting to external consultants for conducting a pre-implementation analysis of the company's needs. The relatively small relevance of such a strategic factor as the reorganisation of the SME to prepare it for the post-implementation reality came as a surprise.

The main value of the study is the collection of opinions and suggestions from a sample of respondents with very valuable, up-to-date work experience in SMEs concerning the CSFs of implementation of CRM/ERP systems in SMEs in Poland. Its findings add to a growing body of literature on the subject of digitalisation of companies, with the focus on SMEs.

As far as practical implications of the study are concerned, the findings can be useful for decision-makers of SMEs and can help them to prioritise factors they have to take into account while making the strategic decision of undergoing implementation of an ICT system to improve their operational efficiency and competitiveness.

As the study was meant as a pilot study, its limitations include the lack of research on a larger sample. Further work should also cover the main barriers and threats connected with the implementation of ICT in SMEs in Poland and the ways of overcoming them. Research into this area is already underway. On a wider level, studies are also needed to define CSFs for larger Polish companies.

\section{References}

1. Adam, F., and O'Doherty, P. (2000). Lessons from enterprise resource planning implementations in Ireland - towards smaller and shorter ERP projects. Journal of Information Technology, Vol. 15, No. 4, pp. 305-316. doi:10.1080/02683960010008953.

2. Ahmad, M.M., and Pinedo-Cuenca, R. (2013). Critical success factors for ERP implementation in SMEs. Robotics and Computer-Integrated Manufacturing, Vol. 29, No. 3, pp. 104-111. doi:10.1016/j.rcim.2012.04.019.

3. Alshawi, S., Missi, F., and Irani, Z. (2011). Organisational, technical and data quality factors in CRM adoption - SMEs perspective. Industrial Marketing Management, Vol. 40, No. 3, pp. 376-383. doi: 10.1016/j.indmarman.2010.08.006.

4. Cieśla, M., Szczucka-Lasota, B., and Wolniak, R. (2018). Analiza korzyści wdrożenia systemu informatycznego klasy ERP w przedsiębiorstwie branży kurierskiej, Zeszyty Naukowe Politechniki Śląskiej, Organizacja i Zarządzanie, 132, pp. 167-179. doi: 10.29119/1641-3466.2018.132.10. 
5. Doom, C., Milis, K., Poelmans, S., and Bloemen, E. (2010). Critical success factors for ERP implementations in Belgian SMEs. Journal of Enterprise Information Management, 23(3), pp. 378-406. doi: org/10.1108/17410391011036120.

6. Dudziak, A., Stoma, M., and Rydzak L. (2017). Narzędzia klasy ERP w strategii zarządzania systemem produkcyjnym. Zeszyty Naukowe Politechniki Śląsiej, Organizacja i Zarzadzanie, 113, pp. 53-66. doi: 10.29119/1641-3466.2018.113.4.

7. Esteves-Sousa, J., and Pastor-Collado, J. (2000). Towards the unification of critical success factors for ERP implementation. Proceedings of $10^{\text {th }}$ Annual Conference Business Information Technology (BIT). Manchester.

8. Eurostat (2018). Integration of Digital Technology by Enterprises. Retrieved from: https://ec.europa.eu/digital-single-market/en/integration-digital-technology, 20.09.2019.

9. Grochowski, K. (2016). Zarządzanie strategiczne w przedsiębiorstwach usług transportowych a proces kształcenia studentów z zakresu systemów klasy ERP. Zeszyty Naukowe Politechniki Ślaskiej, Organizacja i Zarzadzanie, 93, pp. 163-172.

10. Grzeszczak, M. (2018). Zatrudnienie w sektorze MSP determinantem rozwoju gospodarki lokalnej. Zeszyty Naukowe Politechniki Śląskiej, Organizacja i Zarządzanie, 129, pp. 123-142. doi: 10.29119/1641-3466.2018.129.9.

11. GUS (Główny Urząd Statystyczny, Statistics Poland) (2017). Społeczeństwo informacyjne w Polsce Wyniki badań statystycznych z lat 2014-2018, Available online: https://stat.gov.pl/obszary-tematyczne/nauka-i-technika-spoleczenstwo-informacyjne/ spoleczenstwo-informacyjne/spoleczenstwo-informacyjne-w-polsce-wyniki-badanstatystycznych-z-lat-2014-2018,1,12.html.

12. Haddara, M., and Zach, O. (2011). ERP Systems in SMEs: A Literature Review. Proceedings of the 44th Hawaii International Conference on System Sciences. Hawaii: IEEE, pp. 1-10.

13. Kmieciak, R. (2010). Systemy CRM a funkcjonowanie małych i średnich przedsiębiorstw $\mathrm{w}$ dotychczasowych badaniach empirycznych In: Knosala, R. (Eds.), Komputerowo zintegrowane zarzadzanie. T. 1 (pp. 686-694). Opole: Oficyna Wydawnicza Polskiego Towarzystwa Zarządzania Produkcją.

14. Koh, S.C.L, Gunasekaran, A., and Cooper, J.R. (2009). The demand for training and consultancy investment in SME specific ERP systems implementation and operation. International Journal of Production Economics, 122(1), pp. 241-254.

15. Kokot-Stępień, P. (2017). Zarządzanie innowacjami jako źródło konkurencyjności małych i średnich przedsiębiorstw. Zeszyty Naukowe Politechniki Śląskiej, Organizacja i Zarzadzanie, 114, pp. 221-230. doi: 10.29119/1641-3466.2017.114.18.

16. Máté, D., Erdei, E., Zeynvand, V., Popp, J., and Oláh, J. (2020). Can internet in schools and technology adoption stimulate productivity in emerging markets? Economics and Sociology, 13(1), pp. 182-196. doi:10.14254/2071-789X.2020/13-1/12. 
17. Nagy, J., Oláh, J., Erdei, E., Máté, D., and Popp J. (2018). The Role and Impact of Industry 4.0 and the Internet of Things on the Business Strategy of the Value Chain-The Case of Hungary. Sustainability, 10(10), p. 3491. doi: 10.3390/su10103491.

18. PARP (Polska Agencja Rozwoju Przedsiębiorczości, the Polish Agency for Enterprise Development) (2018). Raport o stanie sektora matych i średnich przedsiębiorstw $w$ Polsce. Warszawa. Available online: https://www.parp.gov.pl/component/publications/ publication/raport-o-stanie-sektora-msp-w-polsce-2018PARP.

19. Rockart, R.F. (1979). Chief executives define their own data needs. Harvard Business Review, 57(2), pp. 81-93.

20. Rostek, K., Wiśniewski, M., and Kucharska, A. (2012). Cloud Business Intelligence for SMEs Consortium. Foundations of Management, 4(1), pp. 105-122. doi:10.2478/fman2013-0006.

21. Śledziewska, K., Gabryelczyk, R., and Włoch, R. (2015). Diagnoza luki w kompetencjach cyfrowych MSP [Diagnosis of the SME digital competence gap], No. 1. Warszawa: Digital Economy Lab UW.

22. Somers, T.M., and Nelson, K. (2001). The impact of critical success factors across the stages of enterprise resource planning implementations. Proceedings of the $34^{\text {th }}$ Hawaii International Conference on System Sciences, Hawaii.

23. Sun, A.Y.T, Yazdani, A., and Overend, J.D. (2005). Achievement assessment for enterprise resource planning (ERP) system implementations based on critical success factors (CSFs). International Journal of Production Economics, 98(2), pp. 189-203.

24. Wolniak, R. (2005). Model komputerowego systemu zarządzania jakością [A Model of Quality Management Computer System]. Zarzadzanie Przedsiębiorstwem, 1, pp. 77-93.

25. Wolniak, R. (2017). Oprogramowanie do komputerowego wspomagania metody QFD [Software for computer-aided QFD]. Systemy Wspomagania Inżynierii Produkcji, 6(6), pp. 234-246.

26. Wolniak, R., and Hąbek, P. (2014). Systemy komputerowe raportowania Społecznej Odpowiedzialności Biznesu [Computer Systems in Corporate Social Responsibility Reporting]. Problemy Jakości, 9, pp. 32-36.

27. Wyskwarski, M. (2016). Systemy ERP w modelu cloud computing [ERP Systems in Cloud Computing Model]. Zeszyty Naukowe Politechniki Ślaskiej, Organizacja i Zarządzanie, 99, pp. 613-628.

28. Zastempowski, M., and Glabiszewski, W. (2017). Marketing innovations of Polish small and medium enterprises. Zeszyty Naukowe Politechniki Ślaskiej, Organizacja i Zarzadzanie, 114, pp. 649-661. doi: 10.29119/1641-3466.2018.114.50. 